\title{
Developing Multi-Literacy Skills by Creating Graphic Story in Literature Class: A Project-Based Learning Approach
}

\author{
Rahmad Hidayat and Fajar Susanto \\ English Language Education Department, Faculty of Social Sciences and Humanities, Universitas PGRI Adi Buana Surabaya
}

\begin{abstract}
The research aims to develop multi-literacy skills by creating a literary graphic story as a creative and innovative way for English Department students in learning literature. By creating an adaptation from text to picture, students are expected to improve their ability to understand literary works and express their creative and innovative skills. This is a qualitative study implementing the Project-based Learning (PBL) approach in literature class, which aims to produce graphic stories as the output of studying literature. Students do not only understand the literary theories but also make something out of their understanding. The scaffolding instruction method was employed to examine practices of improving multiliteracy skills. A detailed action research plan, including preliminary observation in the classroom, action plan, intervention, and guiding, is applied. The investigation related to the barriers in doing the project is going to be conducted as well. Reader Response criticism is introduced to students in the reading and analyzing stage as a useful method to develop their critical thinking in evaluating the literary works they read. We argue that the students improve their reading skills, writing skills and producing graphic story stories based on their own interpretation of the literary text, which is proven by the summary and conversation texts they produce in the graphic stories. They also develop their creativity by producing images and pictures as the result of the literary adaptation process. There are two significant outcomes of the project: developing literary text understanding as well as producing the original graphic story.
\end{abstract}

ARTICLE HISTORY

Received 15 April 2020

Accepted 17 June 2020

Published 31 December 2020

\section{KEYWORDS:}

Multi-literacy skills, graphic story, literature class, and project-based

\section{Introduction}

Educators and teachers' concern wherever around the world is how to make their learning and teaching process better and better than before. To reach the goal, we can see that there is a lot of research and projects are done to get new methods and approaches in teaching literature so that they can be applied in the classroom. One of the current issues is how to develop multi literacy skills for students so that they have valuable skills to endorse their academic knowledge and support their success in their career in the future. Studies on developing students' multi-literacy skills are mushrooming, and yet the use of graphic novels as literary adaptation is left unexplored.

Empowering university students' literacy skills is crucial since the lack of reading and writing becomes a common phenomenon in Indonesia, especially for students at all levels. It needs continuing attempts to improve literacy ability by doing some researches and implementation to reach the goal. Literacy is a significant issue in education (Blue, 2010). Literacy itself, he argues, is the combining of two 
skills, reading and writing. Multiliteracy skills are also blended by elaborating reading and writing multimodal mediums such as text and images (Kyle et al., 2004).

Literacy skills have also become the current issue due to the massive development of information and technology and the appearance of revolution 5.0 around the world. Teachers everywhere face the same problem related to the literacy matters (Bitz \& Emiajulu, 2016). They argue that engaging students to read and write as the basic literacy skills is unfinished work for educators. The massive development resulted in new challenges for educators to minimize the negative impacts of the development, which is called distraction. The distraction refers to the huge consumption of the internet and social media among people worldwide. It breaks the focus on the nowadays students, the so-called millennial generation.

In the future, the literacy skills move to multi-literacy skills. These are the skills that combine multi modes skills as media to improve students' literacy skills, such as the use of text and images media in which in this research is the graphic story. Griffith (2010) states that in the 21 st century and the age of developing multi- media in life. That is why educators need to prepare the students to face the age by leading them to have multiliteracy skills.

Writing a graphic novel is a promising method to encourage multimodal skills literacy for students in the 21st century (Hughes et al., 2011). Some educators believe that guiding students to read and write a graphic novel has some advantages. First, since the graphic novel provides both text and picture, it can be a joyful source. Second, creating a graphic novel done by students contributes good multimodal skills for the students' success in the upcoming era. It is because creative and innovative skills will be extremely needed to develop information and technology now and in the future. They also emphasize that graphic novels can motivate students to have multiliteracy skills.

Therefore, this research is intended to answer the challenge by developing literary comic strip as the literary adaption from text to visual image in the literary comic strip. This is an effort to improve students' understanding of literary works and encourage the students to be creative and innovative students by creating a literary comic strip. This research also offers the humanistic approach in analyzing literary works (Harper, 1988). He argues that teaching literature at the undergraduate level should be delivered in a humanistic approach, which means that it encourages students to express their ideas when they interpret literary works.

In line with Harper's insight, this research elaborates the humanistic approach by allowing them to explore their interpretation in analyzing four short stories as the literature class project. By adopting from text to graphic story, the students interpret the story based on their understanding of the content and the authors' theme. The result of the interpretation is a graphic story version. Through the creating of the literary comic strip as new media as the product of literary adaptation, the students follow the steps which lead them to practice their literacy skills begins from reading literary works, analyzing and examining the text, evaluate the text and then reproduce the text by creating new media in the form of images.

Unlike Hughes' project, which focuses on creating by graphic novel as original work, this research project focuses more on the adaptation from literary text to the literary graphic. For some reason, this graphic novel is the trigger for students to be creative and innovative. They do not have the basic knowledge to analyze and understand literary works in deep since their major is teaching and education, not literature. The facility is also different in which Hughes and friends have good sources to help them their project comes true, such as internet connection and a good library. Hence, literary adaptation is a reasonable reason to get students creative and innovative and have good multiliteracy skills. This research is also designed to produce literary comic strips as the adaptation product from the students' short stories. Thus, it is hoped that the result of the research can be used as the model to develop multiliteracy skills for students of English as a Second Language classroom.

\section{The Use of Graphic Story in Classroom}

Creating and using graphic novels to develop students' literacy skills is not new, especially in learning English as a second language (Isa, 2017). It is proved that graphic novel offers some advantages since it provides text and picture as joyful materials to attract students to learn and study about literary works. Fascinatingly, the graphic stories are used broadly in the classroom as means to improve literacy skills in some areas of studying the language (Barter-Storm \& Wik, 2020; Carano \& Clabough, 2016). In their class in Toronto, Canada, Janette Michelle Hughes et al. (2011) did a project by creating a graphic novel in their classroom with their students. They reassure students by using comics. Life software as a tool to create 
the graphic narrative. They confessed that the project was challenging since the students are not too familiar with making their own stories and images. However, it can be solved by triggering the students to tell their own life experiences so that they make a graphic story based on their past life experiences.

The next research was conducted by Bitz and Emiajulu (2016) in Nigeria believe that comic books are really useful tools that teachers can use to explore the students' creativity. The comic also proved that it is a good source to motivate students to read and write. They even did some stages to implement the comic books as literacy building start from writing, designing, and publishing their original comic story.

While in Malaysia, Yusof et al. (2017) tried to see teachers' perspectives about the use of graphic novels as materials in teaching English as a second language (ESL). They investigated the role of the teacher in doing graphic novels in the classroom by observing 57 participants. Based on their research, they found that along with the IT era, the use of graphic novels should be applied in ESL classrooms due to the benefits of the media. However, they recommended that the teachers who apply the graphic novels should be trained first so they can practice it in class well. The researchers also proposed that the government support the teachers to have good knowledge of graphic novels as the teaching instrument.

The more practical in using graphic novels as learning media was done by Paula E Griffith (2010) in the United States of America. She explored how to use graphic novels in the classroom and proposed good graphic novels such as the color, the content of the story, and the connectivity between texts and the images represented in graphic novels. She recommended using various genres such as humor, social, and adventure to enrich students' reading materials.

In Germany, Bridges (2009) promoted the use of graphic novels in the classroom. Through her article, she shared her experience when applied the materials. She contended that graphic novel motivates students to increase their multiliteracy skills. From the literature review above, it can be concluded that there are a lot of researches about multiliteracies, which are applied to graphic novels in the classroom. We can also see that the research was conducted in many countries worldwide to improve students' literacy skills and ability from primary schools to higher schools. This shows the relevance of graphic novels as a means of learning and teaching, especially in English as a Second Language classrooms.

However, the creation of Graphic Novels as the product of literary adaptation is still limited and very few. Therefore, this research will enrich the previous studies concerning graphic novels and promote the new approach of improving multi-literacies for students and innovative learning in terms of studying literature and English as a Second Language. For this reason, the discussion is conducted to answer some questions. First, how is the literary adaption implemented in a literature class? And the second is how do the students create the graphic story to improve their multiliteracy skills?

\section{From Text to Picture: A Literary Adaptation}

As mentioned before, the research is conducted to encourage the students to explore their ideas in analyzing literary work creatively and innovatively by resulting in new media, namely graphic novel. The activity is called a literary adaptation, in which the students transfer from the short story they read to the graphic novel. The process of literary adaptation is very common in literary studies. Linda Hutcheon (2006) notes that the adaptation in literary studies has a long history. It can be traced since the Victorian era when some literary forms such as poems, drama, and novels were adapted into another medium, such as the poem adapted into opera. In addition, Hutcheon explains that adaptation is the process of transformation from one medium into another medium.

The common phenomenon of the literary adaptation is filming novel or drama. To mention them are Romeo and Juliet, Hamlet, Harry Potter, The Lord of the Ring, Twilight, Love at The Time of Cholera, and still many more. It can also be seen in Indonesia through films adapted from fiction, such as Laskar Pelangi, Tenggelamnya Kapal Vanderwijk, Ayat-ayat Cinta, and so forth. However, the trend of literary adaptation in the current.

In a further development, graphic novels' publication as the literary adaptation product becomes more attractive nowadays. There are at least four reasons why graphic novels are produced massively; easy to follow, easy to understand, fun, and shorter (Brooks, 2016). That is why there is a rising trend in adapting classic novels into graphic story version. To mention them are Jane Eyre, Great Gatsby, and The Odyssey.

Kyle Meikle (2013) argues that adaptation in literary studies is a transformation process from one material to another. The adapter uses the work which is going to be adapted as the source and raw 
material. By quoting George Bluestone, Meikle explores that adaptation is conducted to get new forms like film and vice versa due to the adaptation process. She also sees that the result becomes unique work since it provides a creative new form.

\section{Method}

\section{Research Design}

This is a qualitative study implementing Project-Based Learning (PBL) approach in literature class, English Education Department University of PGRI Adi Buana Surabaya. PBL was chosen because students' production is designed as the outcome of the learning process to develop the students' multimode skills (Veselov et al., 2019). Furthermore, PBL is a way to lead students to gain a deeper understanding of materials, which is called a constructivist finding (Krajcik, Phyllis \& Morais, 2018). It encourages students to do a learning process by elaborating at least three phases: understanding the subject, doing collaborative learning in a group, and then creating a product as the final learning process.

In implementing PBL, the scaffolding method was employed in class. Scaffolding instruction refers to teachers' guidance to the students in doing tasks successfully (Hammond \& Gibbons, 2001). From an early stage, the teachers give the students instruction to develop understanding and skills (Jumaat \& Tasir, 2014). The scaffolding instruction also helps the students learn independently.

The literature class has 14 meetings in total. The scaffolding method in implementing PBL was incorporated into the class meeting schedule and structured in five phases as follows:

In the first phase, which was given in the first and second meetings of the class, the students were given a basic understanding of literature. The stage discussed the definition of the elements of literature. The students were given reference books that they read and studied about the intrinsic and the extrinsic of literary works such as character and characterization, theme, setting, plot, point of view, and conflict. Then the students read the extrinsic elements of the story; social and cultural background of the story. The phase encouraged the students to understand the elements of the story so that they have the basic knowledge to analyze literary works.

In the second phase, which took place in the third and fourth meetings, the students read the short story to create the graphic story, an adaptation from literary text to the graphic story. After reading the stories, students were introduced to Reader-Response Criticism. Reader Response Criticism focuses on the reader who can interpret literary works based on his/her own knowledge (Tyson, 2009). It means that everyone can freely analyze literary works, and there is no wrong or right related to the interpretation. Furthermore, readers' role in literary studies is to produce meaning so that it gives a lot of opportunities for readers to explore / her interpretation of literary work (Davis \& Womack, 2002). Therefore, the approach offers students to express their ideas and opinion in analyzing literary works they read. As the reader, the students have the freedom to interpret literary works based on their knowledge. The example of analyzing literary work also triggered the students to interpret the content of the story they have read.

Phase three occurred in the fifth and sixth meetings, which was applying the Reader-Response Criticism. In groups, the students discussed the short story. First, they explored the theme, and the issue revealed in the short story. Secondly, the students delivered comments orally to expose their understanding of the story. The question and answer section was delivered at the end of the session. Lastly, they summarize the character, setting, plot, and conflict by deciding the main character and its characterization. His/her role in the story was investigated to see the relationship with the story's content. One of the important elements in the graphic story is making the story's sequence so the students can use the summary to create the story in order from beginning to end. Maggie Chase et al. (2014) call the summary as retelling the story, and it gives the students to write the story they write in their own version in a logical sequence. Through the summary written by the students in the group, it can be seen that the students understand and follow the content of the story. This is an essential material for the students to arrange the sequence of the graphic story they are going to make. Then, identifying the characters is needed to create the image of the characters in the picture. For example, the character of 'me' in the story of the Walls will Talk is depicted as diligent and hard work so that the students draw a strong image in their creation.

Since the article elaborates the literary adaptation from text to picture, the analysis focuses on how the students interpret the four short stories and then adopt the interpretation by creating a graphic story. 
It means that the accuracy between the summary and the sequence of the graphic story that the students made is the article's emphasis. Therefore, the discussion is not trying to scrutinize the students' grammatical errors in writing the summary.

In the next two meetings, which served as the fourth phase, the students were given literary adaptation materials. This phase is essential since the students do not have basic comprehension related to the literary adaptation. Literary adaptation transforms from one genre into another genre, such as from a novel into a film and from text to pictures like a comic or graphic novel. They need to understand the elements of adaptation by considering the elements of the story.

The last phase is creating a graphic story, which lasted for the next six meetings. Before starting, the students were instructed to imagine the situation or the story's setting. The theme of the story gives them an insight into the situation of the story. For example, the stories entitled Mariana and The First Day of School reveal the issue of education. The students explore the issue by drawing the situation in school. In the Legacy story, the students interpret the environment that demonstrates the practice of illegal logging. This inspires the students to draw the people's activity in the forest to do the illegal logging. The last story is The Walls will Talk, which tells about the social problem as a single parent. The students explore the image of a woman who live without a husband. The image of characters created by the students in the graphic story is also interesting to represent the story.

\section{Data Collection}

The study's data are graphic works collected from the sophomore students of English Education Department University of PGRI Adi Buana Surabaya who took 'Introduction to Literature' subject in Semester 1, 2020. Sixteen students were divided into four groups in which each group discussed one story. The story was read by the students and then used as the material to create the graphic story. The short story was chosen as the project of creating a graphic novel because of some reasons. First, the story's length is quite short compared to novel so it is easier for the students to read and understand. Second, the plot of the short story is not as complicated as novel. The following reason is considering the students' ability to transform the story from text to picture verse which means that the text is much shorter than novel so it is easier for the students to transform the story into graphic story. There are four short stories selected, namely Legacies by Kevin Sandefur, Mariana by Erni Aladjai, These Walls will Talk by Teguh Affandi, and the First Day of School by Jeffery Deaver. The stories were taken from various resources widely available, such as newspapers and websites on fictions. The four stories were chosen because they were written in accessible English and that they discuss social issues familiar to the students, such as education, social and environmental problems. It is expected that the students can follow the stories since the issues become common issue in the society.

There were four graphic stories produced in the class, based on the four stories assigned to each group. Three graphic stories were drawn manually, and one story was produced using a drawing computer software. These graphic works were then analyzed qualitatively to explore the students' creativities in adapting texts into pictures.

\section{Finding and Discussion}

It needs creativity to lead the students to enjoy studying literary works. One of the interesting strategies which can be implemented in the class is project-based learning. This enables the students to be not only literary work consumer or reader but also to encourage them as creators as shown in this project, namely graphic story as the literary adaptation from text to picture. The students also explore their ability in expressing the understanding of literary works. They showcase their ability when they make the graphic story as the result of their reading. Here, the role of an educator to motivate students is crucial since they may have little knowledge in literary studies, especially literary works written in English.

The four graphic stories produced by the students as the outcome of literature class also show that studying literature offers lot of opportunities to interpret based on the students' own knowledge. Through several meetings, the students can follow the process of understanding literary works by reading, analyzing, writing a summary and then creating graphic story. In short, the four activities which are done by the students contribute significantly to the result of the graphic story. 
Therefore, it is important to get the students familiar to the story they read because this can be a foundation to move in the next step. Through the summary they wrote as the comment to the content of the story, each group expressed the interest to the narration in the story. The word inspiring is chosen by the students who discussed the story entitled 'The First Day of School". Then, the word 'deep meaning' is written by the students who investigated the story entitled 'Mariana'. The word 'fascinating' is expressed by the students who analyzed the story entitled 'legacies'. In the meantime, there is no clear expression written by the students in the story of 'the walls will talk.'

Through the summary, the students can identify the intrinsic elements of the stories such as the characters and the characterization, the conflict and the sequence of the event. Interestingly, the students also explore the moral message which is revealed in each story. In the story 'The First Day of School,' the students stated that it is good for students and teachers to get the values because the story tells about education. In the summary of 'Mariana,' the students explicitly note that the story teaches about how to care and understand other people. In the 'Legacies' story, the students narrated clearly about the illegal logging which affects the environment. The students who discussed 'The Walls will Talk' did not explore the moral value. They only re-wrote the story based on their understanding.

The summary, which contains about the literary elements above, gives basic foundation for the students to create graphic story as the peak activity in this project. It is a guide for the students to illustrate it in the form of images which is supported by the texts inside.

\section{The Analysis of the Graphic Created by the Students}

\section{Story 1: The First Day of School (written by Jeffery Deaver)}

Students' summary [sic]:

We have read "The First Day of School" which is very inspiring story, especially for students and teachers. This story narrates the struggle of Jim Martin in school, but he could improve himself with the power of his teachers' beautiful words. At first, Jim Martin was just a victim of bullying. Luckily, his teacher helped and gave him good words that changed his view of life. Not only that, Jim was also bad at Math. But, again and again, his teacher motivated him and changed him. And we really love when his English teacher praised him, because Jim tried to be different in creative way. At the end, adult Jim became a teacher in his own school. This wouldn't happen without beautiful words from his teachers. We wonder what will happen to Jim, if his teachers didn't motivate him. From this story we realized that a small word could affect someone's life.

It is interesting to see the graphic story made the students in this group (to find the picture please the attachment). As a whole, the graphic story follows the summary they have written in term of the content of the story. Written by recount type, the story tells about the successful of a student whose name is Jim Martin. The role of the teacher contributed to the successful of Martin who got bullying at the first day of his school and to have struggle on Math subject as well.

In the graphic story, the students draw creatively by illustrating the sequence of the event so that the reader can follow the story. The students also demonstrate the content clearly such as the event of bullying, the situation of class and the words of the teacher who motivates Martin as the main character are clear enough as the interpretation from the text. Uniquely, this group draws the students who attend in class and one of the students is wearing hijab or veil. Since the setting of the story is in America, wearing hijab is not common. This shows an original interpretation which is done by the group.

\section{Story 2: Mariana (written by Erni Aladjai)}

Students' summary [sic]:

We have read short story entitled Mariana by Erni Aladjai on Jakarta Post. That story have very deep means. The story tells us about what care, attention, and understanding other people is. The main character of this story is Mariana. Mariana is a patient and kind girl. She never pay back the bad thing that her mates do to her. She have good manner and thought, moreover she is still young. She is in fifth grade on Kalipokan Island at that time. Her father has bad temper, but it is not what he want. He was fell down from coconut tree and his head hit against rock when he was 15 years old. 
After that he is can't handle his anger. His anger very easily to come out. One day, he beat his second daughter with large bamboo pole in the school yard and a lot of students and some teachers saw that thing. Mariana never hates her father but she hates what her father did to her sister.

This group created the graphic story manually by drawing in paper (to find the picture please the attachment). The image looks messy but it is fascinating since the students illustrate the characters vividly. The students are creative when they illustrate the face with angry emotion and the sequence of event is supported by the exploring the scene.

\section{Story 3: The Walls will Talk (written by Teguh Affandi)}

Students' summary [sic]:

In an apartment on the 18th floor, there lived a woman who was ill and could not breastfeed her child. Her child named Jena, she cried so hard that there was a neighbor named Seruni who helped the woman give breastfeed to Jena. After Jena feels better, Seruni leaves them by giving a phone number if the woman needs it. The next day, the woman visited Seruni's apartment and thanked. Then, Seruni suggested to the woman to send Jena to the school located on the ground floor of the apartment and be willing to take care of Jena if she had not returned from the office. Their relationship was very close, until one day Seruni dared to ask about Jena's father who made her feel hurt because she opened her old wounds. The woman forbade Jena to meet Seruni because she felt uncomfortable about the question earlier. Later, Jena asked about her father and made her mother more hurt.

Seruni reassures Jena that her father is in heaven, but Jena's mother forbids Jena from being close to Seruni so that it does not become a part of Seruni's gossip.

This group starts their graphic by illustrating the characters (to find the picture please the attachment). There is one difference between the summary and the graphic story they have made. In summary, they explore the narrator called a woman while in the graphic they use 'me'. The sequence of the story looks simple to express the story but it has nice images.

\section{Story 4: Legacies (written by Kevin Sandevur)}

Students' summary [sic]:

The short story we read is called Kevin Sandeveur's Legacies. This is a really fascinating story. It has the most recent environmental problems, especially illegal logging. This story includes three key characters; Murdock, Spalding and the foreman. Murdock and Spalding are engaged as friends; they are illegal loggers. Everything went smoothly until they were forced to abandon their work one day because their masticator crashed into a prehistoric stone. Spalding saw the stone and told his foreman not to cut down the tree because it had historical significance, but his boss was stubborn and he ordered the stone to be demolished. That sparks a secret conflict before Spalding eventually decides to stop it. Spalding discreetly breaks logging equipment at night. Murdock, who woke up that night, came across Spalding and then Spalding told him about the stone, what he saw in his dream. Spalding struck his mate, Murdock's head before he fainted at the end of the story. The plot ends when some loggers and his foreman wake Murdock up. He talked of Spalding, of what he did last night. Yeah, they think that what Spalding did actually hamper their work. We assume that Spalding is still concerned about the ecosystem, or at least ancient artifacts, and that he is trying to prevent someone who wants to destroy it, even if it is a little rough.

This group used application to create their graphic story through the website https://www.storyboardthat.com/. The use of the application enriches the creation which is made by the students since the other groups make it manually (o find the picture please the attachment). Thus, it provides us a various creation of the graphic stories which are done by the students.

By defining the issue of illegal logging in their summary, the students in this group are creative to make an illustration. They draw a forest as the background with the people who do the illegal logging. Interestingly, the students also explore their resourcefulness by depicting situation of the practice of illegal 
logging with the people who wear helmet and tractor. The caption in every episode also strengthen the plot. In short, the graphic story is easy to follow and understand and it really represents the original which they adapted.

\section{Conclusion}

There are a lot of ways to encourage the students to improve their multi literacy skills. Studying literature can be one of the efforts to fulfill the skills which is crucial for the students as the millennial generation in the current era which is called as revolution industry 5.0. It is because literature offers rich sources in term of text such as novel, novella, drama texts and short story. As the reflection of human life, the students can learn a lot about social, culture, language, education issues and environmental problems revealed through the literary works. Thus, the use of literary works meets the need to support the multi literacy skills for the students especially in literature class.

The students improve their ability in reading skills, writing skills and producing graphic story based on their own interpretation of the literary text, which are proven by the summary and conversation texts they produce in the graphic stories. They also develop their creativities by producing images and pictures as the result of literary adaptation process. There are two significant outcomes of the project: developing literary text understanding as well as producing original graphic story. However, the students still lack in developing their critical thinking in their graphic story and summary since they do not elaborate the issue of education, social and environmental problem which are revealed in the short stories. It is hoped that they are not only retell the story but how they voice the issues through the graphic stories.

The project also promotes the new way in literary studies in which it leads the students to create the graphic story as the output of the literary interpretation. Through the graphic story which is made by the students, studying literature becomes a joyful activity as well as a medium to lead the students to have multi literacy skills. In sum, the project proves the students show their ability in multi literacy skills. Since this activity includes students experience in literary adaptation, it is a big potential for future research to address students' reflectivity in the process as well to incorporate their experiences which cannot be expressed in the graphic works they produce. This could be an additional session class in which the students could talk about their feelings and thoughts while drawing and the negotiation process made with their peers in creating the graphic story.

\section{References}

Affandi, T. (2017, February 6). The Walls will Talk. The Jakarta Post. https://www.thejakartapost.com/life/2017/02/06/short-story-these-walls-will-talk.html

Aladjai, E. (2019, January 28) Mariana. The Jakarta Post. https://www.thejakartapost.com/life/2019/01/28/short-story-mariana.html

Barter-Storm, B, \& Wik. T. (2020). Using Social Justice Graphic Novels in the ELL Classroom. TESOL Journal. https://doi.org/10.1002/tesj.551

Basal, Ahmat, Aytan, T., \& Demir, I. (2016). Teaching Vocabulary with Graphic Novels. English Language Teaching; Vol. 9, No. 9. Canadian Center of Science and Education. http://dx.doi.org/10.5539/elt.v9n9p95

Bauer, E.B., \& Arazi, J. (2011). Promoting Literacy Development for Beginning English Learners. The Reading Teacher, 64(5), 383-386 https://doi.org/10.1002/jaal.45

Bitz, M., \& Emiajulu, O. (2016). Creating Comic Books in Nigeria. International Reflections on Literacy, Creativity and Student Engagement. Journal of adolescent and Adult Literacy 59(4), 431-441. https://doi.org/10.1002/jaal.451

Block, K. (2013). Teacher's Perception on Graphic Novels. Graduate Research Paper. https://scholarworks.uni.edu/grp/31

Blue, G.M. ed. (2010). Developing Academic Literacy. Proquest e book central.

Bridges, E. (2009). Bridging the Gap: A Literacy Oriented Approach to Teaching the Graphic Novel Der Erste Fruhling. https://doi.org/10.1111/j.1756-1221.2009.00049.x

Brooks, J. (2016). Draw with Jazza - Creating Characters: Fun and Easy Guide to Draw. Penguin. 
Brumfitt, C., \& Pierce, S. (2010). In Developing Academic Literacy edited by George M Blue. Pro quest e book central.

Carano, K.T., \& Clabough, J. (2016). Images of Struggles: Teaching Human Rights with Graphic Novels. The Social Studies, 107(1), 14-18. https://doi.org/10.1080/00377996.2015.1094723

Chase, M., Son, E.U., \& Steiner, S. (2014). Sequencing and Graphic Novels with Primary-Grade Students. The Reading Teacher, 67(6). 435-443. https://doi.org/10.1002/trtr.1242

Davis, T.F., \& Womack, K. (2002). Formalist Criticism and Reader-Response Theory. Palgrave. New York.

Deaver, J. (2002). The First Day of School. https://www.jefferydeaver.com/short-fiction/firstday/

Griffith, P.E. (2010). Graphic Novels in the Secondary Classroom and School Libraries. Journal of Adolescent \& Adult Literacy, 54(3), 181-189. Doi:10. 1598/jaal. 54.3.3

Hammod, J (ed). (2001). Scaffolding Teaching and Learning in Language and Literacy Education. NSW Australia.

Harper, S.N. (1988). Strategies for Teaching Literature at the Undergraduate Level. The Modern Language Journal, 72(4). 402-408. https://doi.org/10.2307/327752

Hughes, J.M. et al. (2011). Adolescent and Auto Graphic: Reading and Writing Coming-of-Age Graphic Novels. Journal of Adolescent and Adult Literacy 54(8) 601-612. https://doi:10.1598/jaal.54.8.5

Hutcheon, L. (2006). Theory of Adaptation. Taylor and Francis Group.

Isaa, S. (2017). Comics in the English Classroom: A Guide to Teaching Comics Across English Studies. Journal of Graphic Novels and Comics, 1-19. https://doi.org/10.1080/21504857.2017.1355822

Jumaat, N.F., \& Tasir, Z. (2014, April 11-13). Instructional Scaffolding in Online Learning Environment: A Meta-Analysis [Conference session]. International Conference on Teaching and Learning, Malaysia. https://DOI: 10.1109/LaTiCE.2014.22

Ljugdahl, L. (2010). Creative Strategies with Literature: Developing Literacy in the Classroom. The International Journal of Learning 17(7), http:/ / hdl.handle.net/10453/13467

Martinez, M., \& Harmon, J.E. (2012). Picture/Text Relationships: An Investigation of Literary Elements in Picture Books. Literary Research and Instruction, 51, 323-343. https://doi.org/10.1080/19388071.2012.695856

Meikle, K. (2013). Rematerializing Adaptation Theory. Literature/Film Quarterly, 41(3), 174-183. Salisbury University.

Meyer, C.K., \& Jimenez, L.M. (2017). Using Every Word and Image: Framing Graphic Novel Instruction in the Expanded Four Resources Model. Journal of Adolescent and Adult Literacy, 61(2), 153-161. https://doi:10.1002/jaal.666

Morais, D. G. (2018). Doing history in the undergraduate classroom: project-based learning and student benefits. The History Teacher, 52(1), 49-76.

Sandefur, K. Legacies. https://www.aftermathmag.org/short-story-not-tears.html

Tyson, L. (2006). Critical Theory Today (second edition). Taylor \& Francis Group. New York.

Veselov, G.E. et al (2019). Project-based Learning as an Effective Method in Education. https://www.researchgate.net/publication/334906382_Projectbased_learning_as_an_effective_method_in_education

Yusof, S.M. et al. (2017). Teacher Trainee's Perspectives of Teaching Graphic Novels to ESL Primary Schoolers. The Southeast Asian Journal of English Language Studies, 23(3), 81-96. https: / / ejournal.ukm.my/31/article/view/18122 


\section{Attachment}

The graphic stories produced by the students

Graphic Story 1

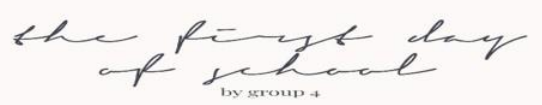
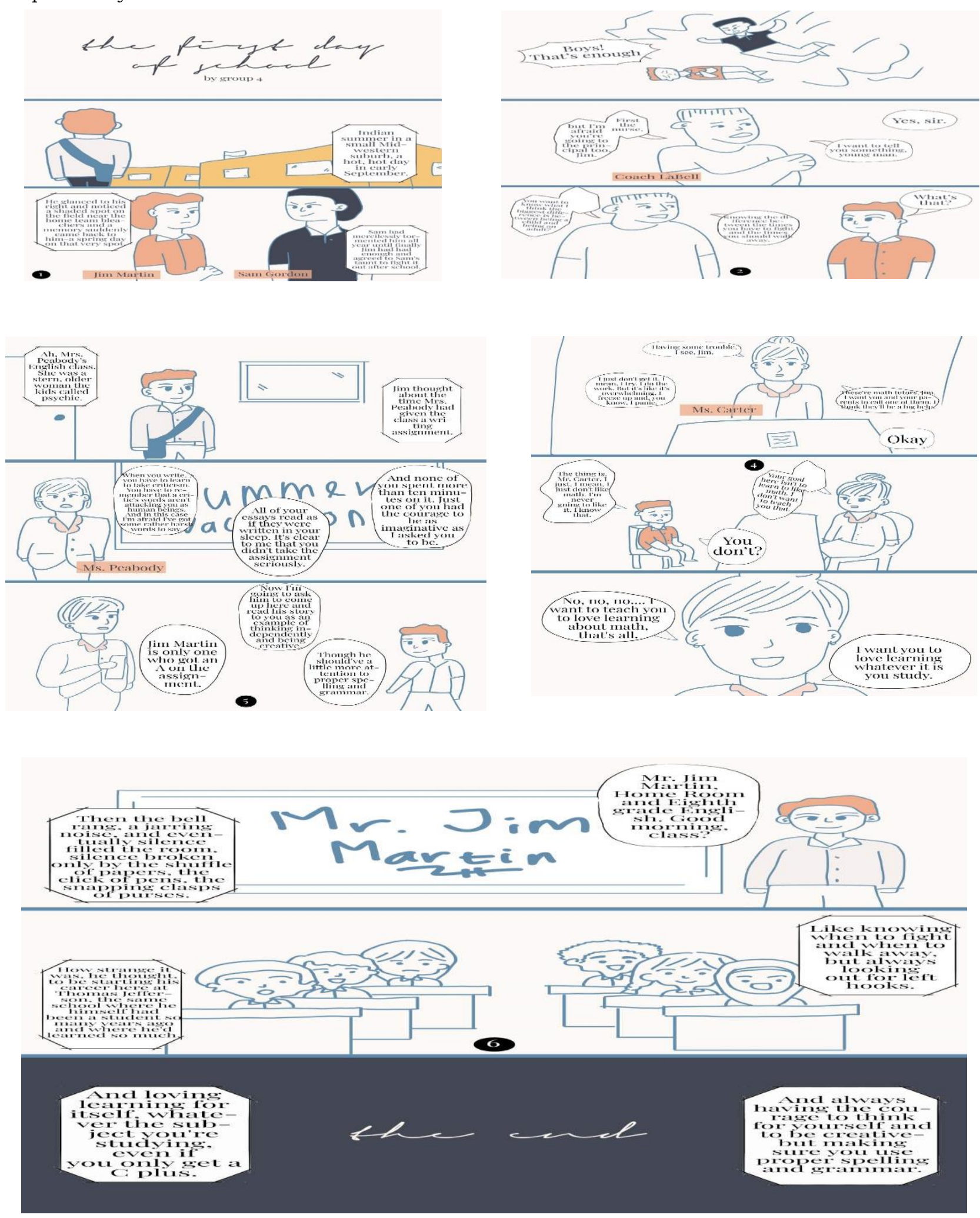
Graphic Story 2

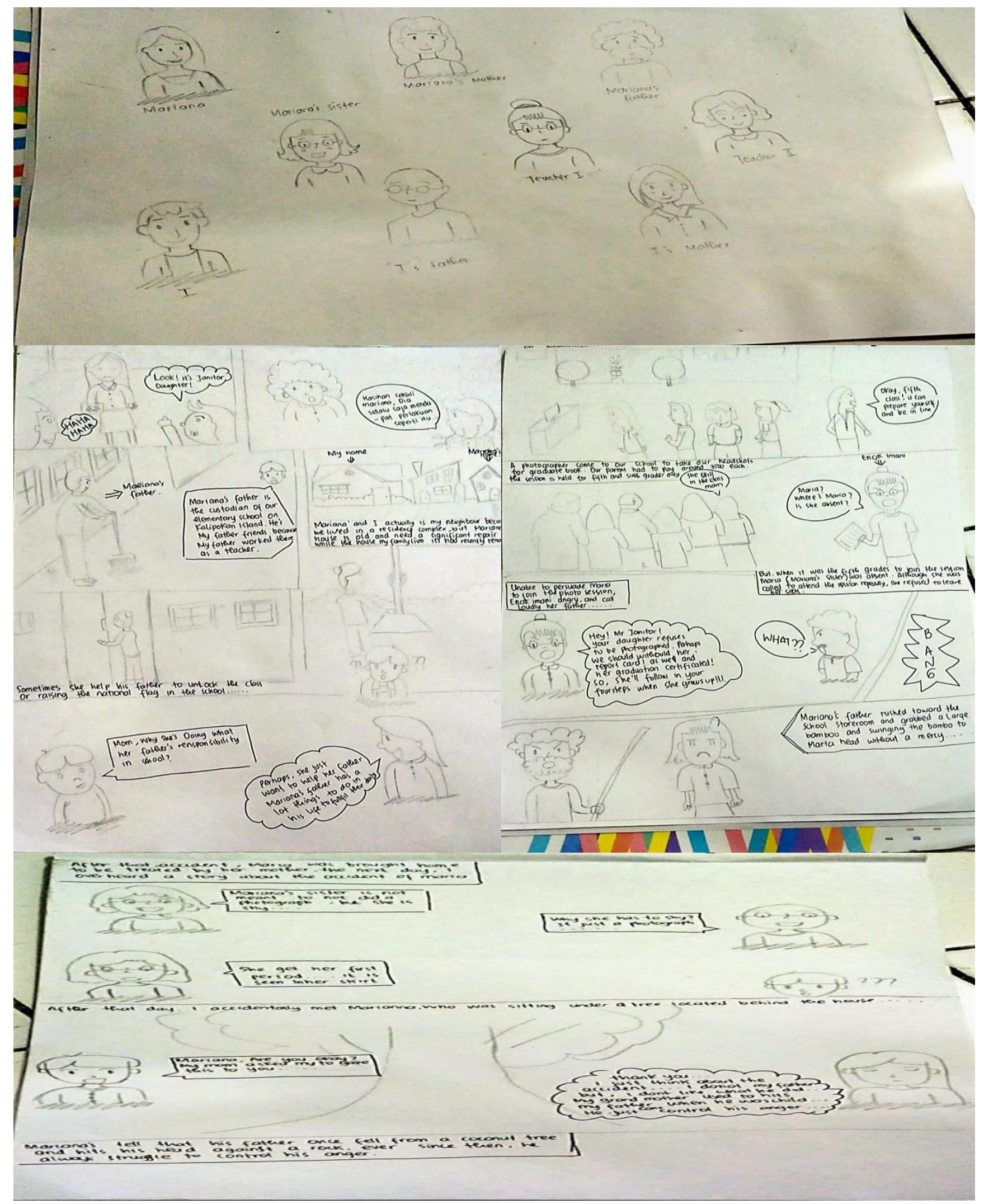


94 JOLI R.HIDAYAT AND F. SUSANTO

Graphic Story 3

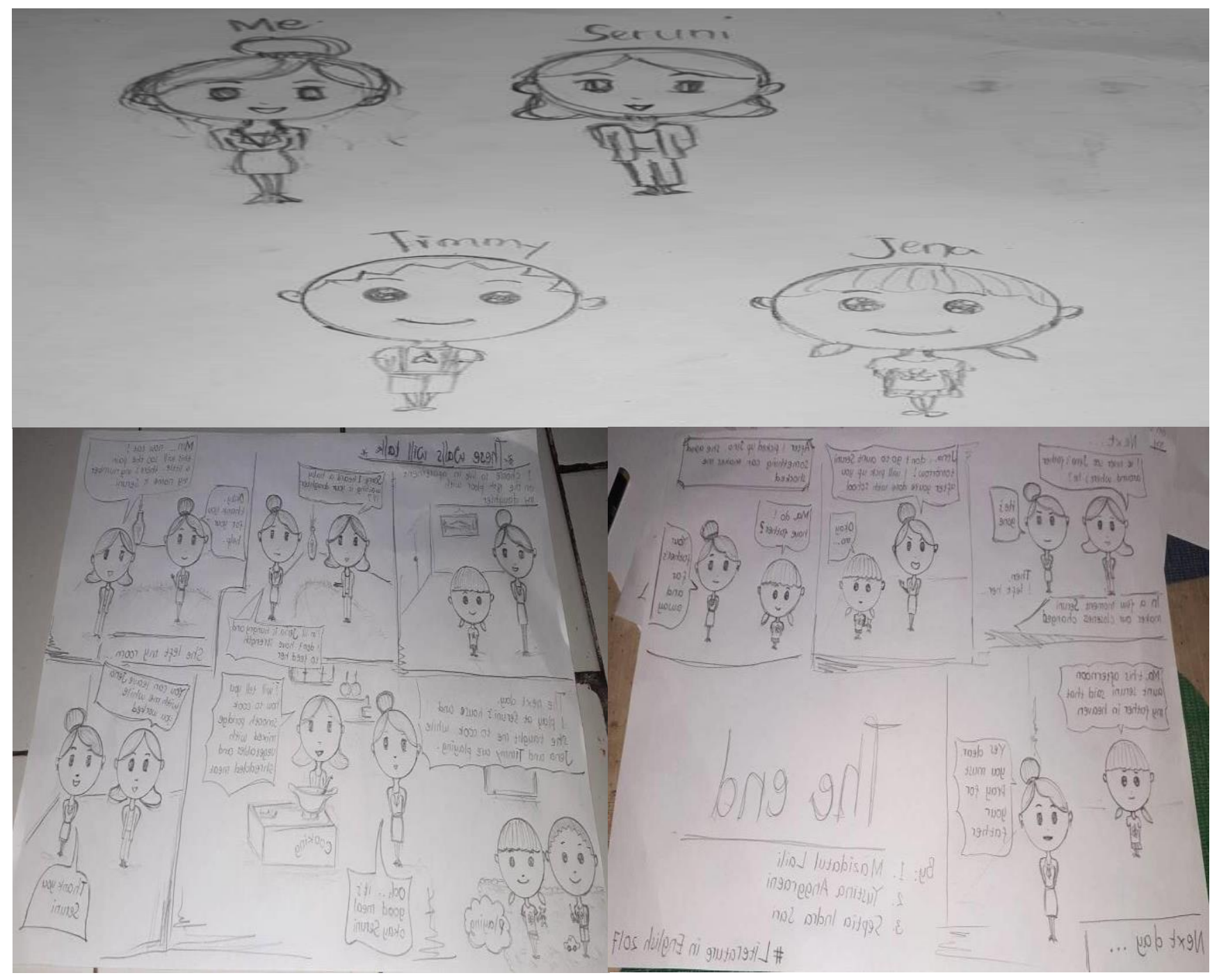


LEGACIES BY KEVIN SANDEFUR (COMIC STRIP VERSION)

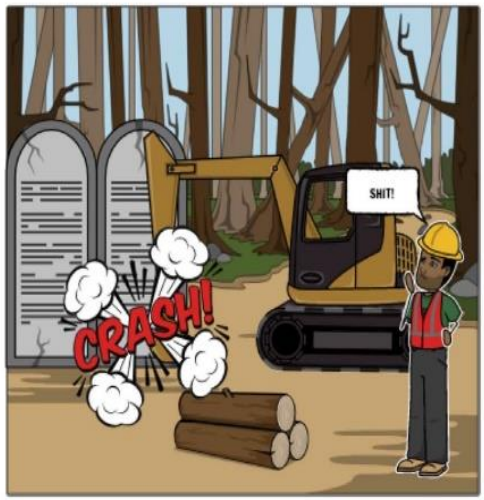

Murdock came down from the cab when he found the stones that were blocking his masticator.

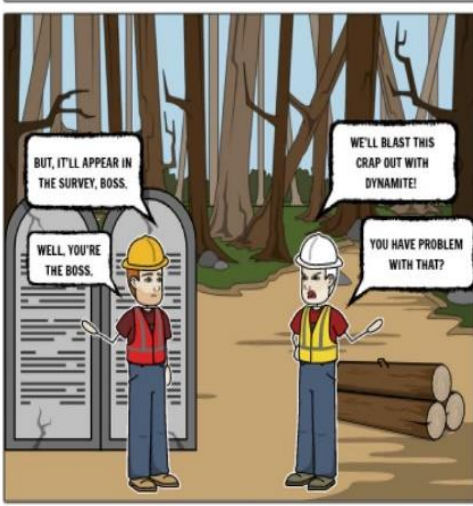

Spalding debated with his foreman about the stones. The foreman insisted on destroying the stones because it was blocking his way.

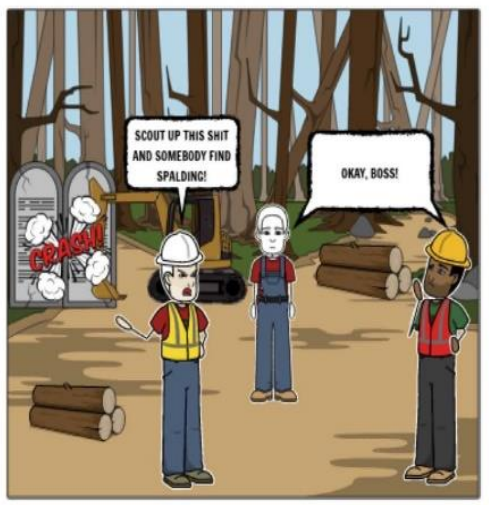

The foreman asked and ordered his men to trace the stone into the rainforest and to find Spalding.

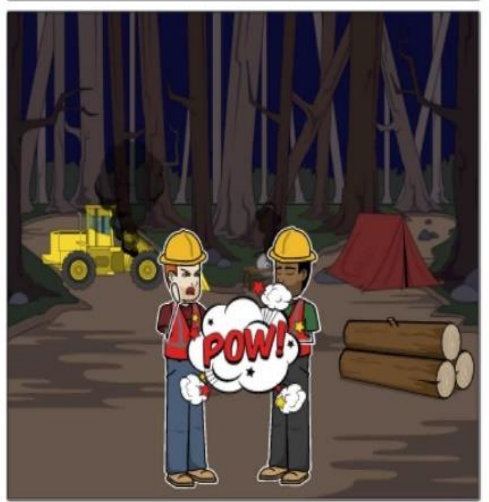

At night, Spalding told Murdock about the stones and struck his head until he passed out. Then Spalding ripped out and destroy the logging equipment.

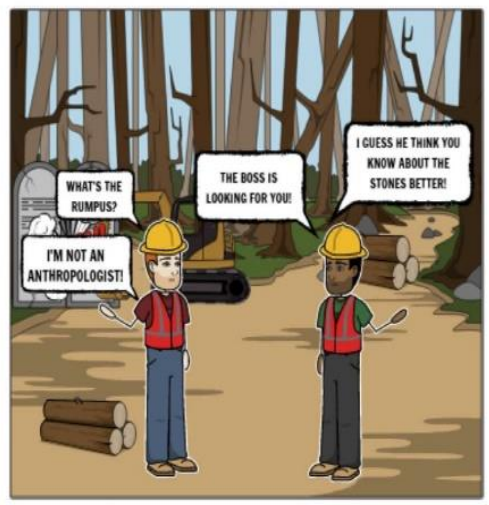
Shortly thereafter, Spalding appeared. Murdock asked
Spalding about the stones and Spalding began to observe it.

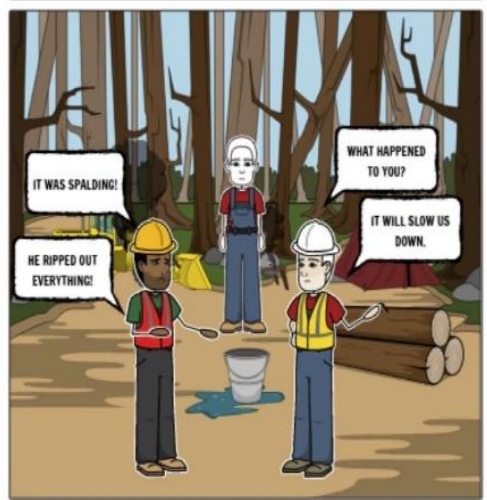

In the morning, the foreman woke Murdock up and asked him. Murdock told that it was Spalding's job last night. Spalding wants to save the stones, any way.

DONE BY ARIF FAJAR NUGROHO, NURUL AINI, YOSHINTA RIZKI AL AZIZ, AND RIZCHI DWI AINUL SAFITRI. 